\title{
Paying the Penalty for Dishonesty: Evaluative Language in Scottish Football
}

\begin{abstract}
Scottish soccer has frequently been a mirror reflecting sectarian tensions at play in society at large, tensions which can make 'Old Firm' matches between the Glasgow teams of Celtic and Rangers something more serious than a game of football. This study explores an incident during which a referee told a trivial lie to the Celtic manager and, because of the ensuing media storm, was eventually forced to resign. During a radio programme discussing the incident various views are put forward, both for and against the referee. I suggest that, in order to account for the evaluative patterns used by the studio pundits and some of the participants in the incident, it is necessary to have some understanding of the underlying social context. The suggestion is that the underlying social features may be responsible for local discursive effects such as graduation, lexical choices and judgemental patterns. An attempt is thus made to connect broad notions of context such as those of Malinowski (1923), and more particularly Hyatt (2005), with more specific effects at the level of discourse. The Appraisal Framework (Martin and White 2005) is used to explore the evaluative representations in the data, particularly those in the area of Judgement.
\end{abstract}

Key words

Evaluation; judgement; capacity; veracity; context; pragmatics; sectarianism; soccer

\section{Introduction}

It is only comparatively recently that studies with a sociolinguistic orientation have paid much attention to the discourses of soccer. The volume Lavric et al (2008) dedicate to the 'linguistics of football' was, perhaps, a sign that the so- 
cial importance and discursive wealth of the world's most popular sport were finally receiving due attention. By contrast, in the fields of Cultural Studies and Sociology/Social History its importance has long been consolidated, through fulllength works such as Hopcraft (1968), Taylor and Ward (1995), Russel (1997), and Featherstone (2009), and in the establishment of an academic journal devoted to the subject. ${ }^{1}$

Sociolinguistics, in its traditional form, has dealt with topics such as regional dialects (e.g. Wolfram 1991), synchronic and diachronic language variation (Meyerhoff 2006: 8) and politeness (ibid: 82). Critical Discourse Analysis, arguably the most socially-concerned of analytical paradigms in linguistics, has concentrated on questions like racism (e.g. Van Dijk 1991), gender (Lazar 2007), the press (Fowler 1991), national identity (De Cillia et al 1999), war (Chilton 1996) and the role of discourse in maintaining power inequalities (Fairclough 1992, 1995). Sport in general, and soccer in particular, have perhaps been considered peripheral to questions of real social importance, and hence less deserving of critical attention. As Jansen and Szabó (1994: 1), however, point out, there are important connections between leisure activities and real social issues. During the first Gulf War, they claim, sporting metaphors in institutional discourse represented:

crucial rhetorical resources for mobilizing the patriarchal values that construct, mediate, maintain, and, when necessary, reform or repair hegemonic forms of masculinity.

Soccer, in linguistic terms, offers a rich field for enquiry. As the most popular leisure activity of a growing number of countries worldwide, it is a tremendous generator of discourse, as fans discuss issues related to the game in pubs, in web forums, in radio phone-ins, and so on. Moreover, although the discourse centres on apparently trivial circumstances, the emotional investment of fans in these events is such that their social relevance is manifest. The connection of fans' team affiliations and (national) identities has been explored by Bishop and Jaworski (2003), Featherstone (2009: 130), and Szabó (2012). Lately Baines (2011, 2013) has studied the question of foreign stars in the Premier League. These high status economic migrants face problems of cross-cultural communication and are subject to racial stereotyping in media representation. Football reports have also been studied for typical phonological patterns by Brazil (1992), while Chovanec (2008) focuses on the foregrounding devices used by journalists.

Where the fields of Cultural Studies and (for example) CDA converge in an inter-disciplinary perspective is fruitful terrain for studies exploring the interpenetration of social and linguistic questions. As Weiss and Wodak (2003: 19) point out in their discussion of interdisciplinarity, insights from sister disciplines are intrinsic to the project of a linguistics with a social dimension. This paper explores the connection between discourse effects in the field of evaluation and the surrounding social context. It suggests that certain evaluative patterns cannot 
be understood without an informed picture of the social context, in this case the sectarian attitudes prevalent in the west of Scotland, which are evoked to account for the evaluation patterns displayed.

\subsection{Social context: Scottish football}

In retrospect the 2010-2011 season was one of the most controversial in recent memory, even by the standards of Scottish football, where passions frequently overflow into hysteria. Overshadowing episodes like the referees' strike, crowd violence at the Old Firm derby, and even the subject of the current study, the Tannadice penalty incident, were the death threats to Celtic manager Neil Lennon. He received parcel bombs, and on one occasion was actually assaulted on the pitch, by an enraged Hearts supporter.

South of the border compulsory seating and rocketing ticket prices for Premier League games have removed some of the notorious tribal features associated with English football during the 1970s and 1980s. The game has become an extremely popular form of entertainment, and the involvement of Sky TV has led to the formation of an armchair culture among fans. In Scotland, however, and especially in Glasgow, it retains the social significance that led Bill Shankly to quip 'football a matter of life and death? I assure you, it's much more important than that.'

This study focuses on an episode that led to the resignation of one of Scottish football's foremost referees, Dougie McDonald. McDonald was guilty of little more than telling a 'white lie' to the Celtic manager, to protect a colleague after an incident in a game.

The events surrounding the Tannadice affair cannot be correctly understood without some acknowledgement of wider social ramifications; and in particular, without bringing sectarianism into the picture. Since 1999, when composer James MacMillan made a controversial speech at the Edinburgh Fringe on 'Scotland's Shame', the country has made some attempts to come to terms with, and defeat, the potentially violent social forces that surface on occasions such as Old Firm derbies. A BBC Panorama programme, in 2005, 'Scotland's Secret Shame' provided compelling support to MacMillan's assertion that Scotland resembles 'Northern Ireland without the guns'. ${ }^{2}$ One commentator in that programme described sectarian bigotry in the following terms:

It is actually embedded very strongly within the culture, particularly the culture of the west of Scotland. And so it's so familiar, it's so routine that people don't actually think - or have not thought until recently - it's a big issue. It's a fact of life. It's part of the way of life of the society. ${ }^{3}$

Like the conflict in Northern Ireland, the sectarian issues in Scotland date from way back, with the most relevant episode the mass immigration from Ireland during the potato famines of the 1850s. Rangers' fans remind Celtic's of their remote 
origins by singing the now-outlawed 'Famine Song', to the tune of the Beach Boys' 'Sloop John B':

I often wonder where they would have been

If we hadn't have taken them in

Fed them and washed them

Thousands in Glasgow alone

From Ireland they came

Brought us nothing but trouble and shame

Well the famine is over

Why don't they go home?

Glasgow Celtic F.C. were set up in 1887 by a Marist brother as a focus for the immigrant Catholic community. Although Rangers, established some years previously, seem at first to have had no specific religious affiliation, they rapidly became a protestant counterweight to Celtic. In Findlay's words (2008), the rivalry between the clubs:

soon spread far beyond the playing field and gradually came to encapsulate many of the deep divisions inside Scottish society by giving popular expression to the "subterranean" strands of working class culture. As Celtic became the symbol of the Roman Catholic Irish immigrant, the underdog, Rangers took on the mantle of Protestantism, Unionism, Scottishness and the Establishment

Over the years the links with the warring factions across the Irish Sea were maintained, with Rangers granting the Orange Order permission to use Ibrox stadium for Orange services (Kaufmann 2008: 184), and Celtic flying the Irish tricolour over the entrance to their ground. By the 1950s, the 'top dog', in the shape of Scottish Football Association's secretary George Graham, member of the Scottish Orange Order, moved to expel Celtic from the league if it refused to remove the flag (Devine 2008: 193).

Celtic and Rangers, together, have won 96 of the league titles disputed since the League's inception in 1890; their domination is complete. This has meant that throughout Scotland supporters of smaller teams have tended to add an 'Old Firm' allegiance to their local loyalty. The social divisions that plague the city of Glasgow are, therefore, also found within Scottish society generally. In Edinburgh, for example, the same Catholic/Protestant divide is carried on, at a lower emotional temperature, by supporters of Hibs and Hearts.

\subsection{The Tannadice penalty incident}

On $17^{\text {th }}$ October 2010 Celtic were playing away to Dundee United at Tannadice. Referee Dougie McDonald awarded them a penalty kick, then went over to 
speak to Steven Craven, assistant referee running the line. After consultation, he changed his decision and gave a dropped ball instead.

This apparently mundane episode sparked off an extraordinary controversy in Scottish football circles, which saw both McDonald and Craven, eventually, lose their jobs. The two officials ran aground on the bureaucratic mechanisms of the Scottish Referees' Association, an organisation responsible for refereeing standards nationally. The SRA monitors all games in the Scottish Premier League (SPL), awarding marks for referees' performances. During their post-match report to SRA observer McBurney, a lie was told and then, more seriously, repeated by McDonald to Neil Lennon a short time later. Here is McDonald's version of events shortly after the match ended:

Steven pulled the communication wire from his arm device he took my earpiece out and he said 'Dougie, what are we going to tell Jim McBurney?' and I said 'Stevie, I don't care what you tell Jim McBurney, tell him anything, tell him you said 'Dougie, Dougie and I came over to clarify' and he went 'right, okay, that's fine'

In actual fact, Craven had not said anything. On the spur of the moment he had acquiesced in a mistakenly-awarded penalty, instead of alerting the referee. If this came to light, he would be reprimanded and marked down by McBurney. The lie, then, was devised as a cover-up, to save Craven from punishment. As we can see from the above, it originated with McDonald, who goes on to say that this was 'no big deal' for him, and adds:

I had nothing to gain by making up some sort of story but I was happy to go along with it admittedly in terms of helping Steven

After the match McDonald repeated this story in a private chat with the Celtic manager, Neil Lennon, who accepted it at face value. Celtic, after all, had won the match, so there was no reason to probe the matter too closely. Since only two participants in the affair, the two men who had invented the story, knew the truth of the matter, it should have finished there, with no-one any the wiser. Unfortunately for both men, McDonald had a change of heart a few hours later and telephoned Hugh Dallas, SRA president, to tell him what had really happened. Dallas insisted that the media be told, and all hell, or at least, the flames of an impassioned media debate, broke loose.

\section{Relevant context}

Many discourse-analytic traditions have recognised the importance of features of context. Malinowski's (1923: 307) description of the context of situation, for example, refers to the 'complex of social detail' (Bloor and Bloor 1995: 248) 
necessary to understand an utterance. In pragmatics, it has been called one of the 'pillars' of the discipline (Verschueren 1999: 75). For critical discourse analysis, which sees itself as occupied with 'the mediation between the social and the linguistic' (Chouliaraki and Fairclough 1999: 16), context occupies a prominent position. In the 'discourse-historical' approach (e.g. Wodak and De Cillia 2007: 327) 'context models', in Van Dijk's (2001) sense are viewed as cognitive stores of meaning, drawn on by discourse participants and their hearers. Conversation Analysis also offers a dynamic view of context in which participants display 'orientations' to institutional features, thereby perpetuating formal and informal social structures (Hutchby and Wooffitt 1998: 146-149).

This study suggests that evaluative language may represent a revealing locus for exploring the interplay between surrounding social factors and local discourse effects (figure 1).

Figure 1. Social context and local discourse effects

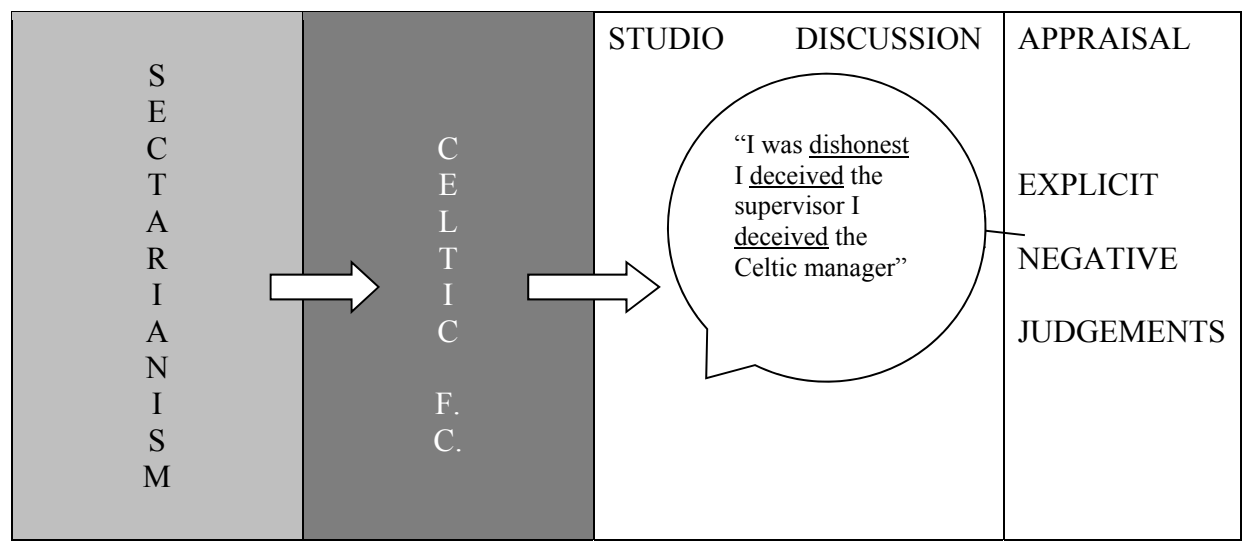

SOCIAL CONTEXT

DISCOURSE EFFECTS

Hyatt (2005) offers a useful model for classifying features of the context of situation which may be relevant for appreciating nuances in discourse. It includes details relating to immediate/medium-term socio-political context, contemporary socio-political individuals, organisations and structures, and 'epoch', or the underlying, quasi-philosophical patterns whereby societies 'legitimate' themselves and achieve a 'social identity' (Hyatt 2005: 522-3). The foregoing description of Celtic's place in Scottish soccer, and the brief outline of sectarianism provided, are not simply colourful background. On the contrary, they provide information about the immediate and medium-term socio-political context that is vital if we are to understand features of the data such as: 
you have Dougie McDonald saying I was dishonest I deceived the supervisor I deceived the Celtic manager

An admission such as this, from a referee, does go against the social expectations associated with this figure which require him to be a model of honesty. I suggest below, however, that the strong negative lexical options are determined by the involvement of the Celtic manager in the specific incident, and by the speaker's awareness of the underlying sectarianism in the social context.

As far as Hyatt's third factor is concerned, relevant social actors are McDonald and Craven (the referees involved in the scandal), Celtic manager Lennon, the SRA and the SFA. Hyatt's notion of 'epoch' is represented by the historical factor of sectarianism, outlined above. For both Rangers and Celtic fans, their football clubs constitute an important source of the contrast between the normative 'us' and the deviant 'them' (Benwell and Stokoe 2006: 223), providing current identities that draw much of their strength from persistent historical factors. Though sectarianism, as a social reality, would seem to belong in a past 'epoch', it actually represents a crucial feature of the current context of situation.

\section{More on the Celtic factor}

It might seem, from what has been said so far about Celtic F.C., that their sense of representing a beleaguered ethnic and cultural minority belonged to the past; that, after sharing domination with Rangers in the domestic league for over a century, they might have become part of the establishment themselves. However, there still seems to be an ethos of victimisation around the club, a sense that the controlling forces of the Scottish game - the SFA, the SRA, and sports' media generally - are all biased against Celtic in favour of the champions of Protestantism/Nationalism, Glasgow Rangers. Writer Tom Campbell (2004) uses the term 'persecution complex' to describe a widespread feeling among the club's current supporters. Through fanzines, blogs and other sources for fans' views the conspiracy theories are given full vent:

Whether it be through the radio waves, the television screen or the written press, Celtic are portrayed as the bad guys and Rangers the good guys. ${ }^{4}$

The sentiment is not confined to the fans. Striker Gary Hooper, for example, although a newcomer to the club, claimed at a press conference early in his first season that referees were biased against Celtic. ${ }^{5}$ Later, the ongoing public wrangling between the club and the SFA led president George Peat to complain: "Celtic's policy of airing their grievances in public is becoming tiresome". ${ }^{6}$

Celtic chairman John Reid was reported as saying, at the club's annual general meeting for 2010: "We will not be treated less than anyone else - those days are gone". The inferences here are, firstly that there is a sense within Celtic that once upon a time they were treated as less than others; and secondly, that the speaker 
is resisting a current attempt to treat the club in a discriminated way. In fact Reid went on to comment on the Tannadice episode, calling for the SFA to reconsider its leniency to the referee involved:

He [McDonald] should go and if he didn't resign he should have been removed from post [...] I believe his position is untenable and I believe the position of the SFA is untenable in protecting him. $^{7}$

Celtic F.C. then, although in national and international terms a huge club, nevertheless demonstrate, on many levels, an uneasy relationship with the Scottish sporting establishment, and this circumstance coloured their response to the Tannadice penalty incident.

\section{Evaluation as an interpersonal resource}

Evaluations, generally, are loaded with interpersonal significance, in the sense of the Hallidayan metafunction (Halliday 2004: 29-30). Martin and White, who developed the Appraisal Framework as an offshoot of Halliday's functional grammar, explicitly locate evaluative language in the domain of 'interpersonal meaning' (Martin and White 2005: 7). This is because expressing evaluation is not simply neutral, in communicative terms. Rather, listeners are automatically engaged in a process of alignment or disalignment as they share or distance themselves from a speaker's evaluation. Martin and White refer to these conscious or unconscious processes as the 'negotiation' of social relations. Through a person's evaluations, a listener can understand if the speaker shares his or her moral and aesthetic value systems, patterns of deep-seated religious belief or more trivial matters of taste and preference. Hunston and Thompson (1999: 6) indicate the intrinsically social, community-building dimension of evaluative language when they say:

Every act of evaluation expresses a communal value-system, and every act of evaluation goes towards building up that value-system.

As Martin and White (2005: 95-97) explain, speakers or writers can use evaluative language either to engage with an imagined or ideal hearer/reader who shares their 'attitudinal assessments and [...] beliefs or assumptions about the nature of the world, its past history, and the way it ought to be', or can be won over to their view. It is easy to see that, in a social context such as that of Scottish soccer, where tribal loyalties are based on often bitter sectarian divisions, evaluation of episodes and personalities may evoke responses that seem, to the uninformed outsider, bizarre over-reactions. Each fresh episode, however trivial, is seen by both sides as the latest in a long history of abuses, and a verbal war may begin, whose first casualty is objectivity. 
The Appraisal Framework is the most comprehensive system dealing with evaluative language, and is sufficiently well-documented to make further introductory comment unneccessary (see, for example Martin 1999, Martin and White 2005). I am mostly concerned with what they term 'Judgement' values, or evaluations of human behaviour.

Evaluative language, in the following analysis, is considered in two senses. Firstly, in terms of the speakers' rhetorical ends. For example, when referee McDonald uses the euphemism 'white lie' to represent his action, it is plain that he does so in order to diminish the gravity of his offence. This is because everyone knows that 'integrity' ( $+\mathrm{J}$ : veracity) or 'honesty' $(+\mathrm{J}$ : veracity) are important values for any referee, whilst 'duplicity' and 'deceitfulness' (- J: veracity) are the opposite. Secondly, these instances are explored in terms of how they might reflect participants' awareness of the relevant social context. Van Dijk (2000) refers to awareness of context as 'general (socially-shared) knowledge'. I suggest, in fact, that it could be because his awareness of the 'Celtic factor' is so acute that pundit Jim Traynor's evaluations of McDonald's behaviour are so severe:

it's a lie he's been dishonest he's been deceitful (-J: veracity, intensified)

Such evaluations come from the 'social sanction' system (Martin and White 2005: 53), which relate to the weightiest judgements on human behaviour, subdivided into two categories, 'veracity' and 'propriety'. The data reveals a pattern of interplay between such judgements and those of a 'social esteem' type, for which the keywords are 'normality', 'capacity' and 'tenacity'. Thus, when Traynor later refers to McDonald as

a top-class one of the best referees in the country ( $+\mathrm{J}$ capacity, intensified)

he distinguishes between his professional capacity and his moral character.

In the following analysis I suggest that negotiation in the area of evaluative language, as participants argue over the gravity of McDonald's behaviour, can only be correctly understood with reference to the sectarian social context.

\subsection{Data: BBC Sportsound, 1 November 2010}

BBC Sportsound is a programme that covers Scottish football. In the edition of $1^{\text {st }}$ November 2010, Dougie McDonald gave an interview in which he talked at length about the Tannadice incident; his remarks were then commented on by participants in a studio discussion. I concentrate on the views of pundits Jim Traynor, who presents the case for McDonald's dismissal, and the more lenient Chick Young who wants him to continue.

As one might expect of one whose career is at stake, McDonald offers a defence of his actions, in which evaluation features strongly (see Appendix A). He argues that he is not simply an efficient, able referee; 


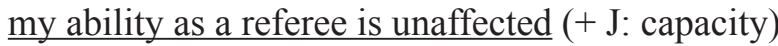

He also claims to possess noteable personal integrity, a quality that specifically fits him for his professional service:

the more difficult thing the more courageous thing the more honest thing was to overturn and make sure that a right decision was arrived at (+ J: propriety/veracity, intensified)

As for the lie itself, McDonald downplays its significance by low-grade lexical choices and euphemistic reformulation:

It was $a$ white lie in the heat of the moment

it was no big deal

I was happy to go along with it

the untruth was told

telling the observer the incorrect situation

In the pundits' discussion, Jim Traynor (Appendix B) makes the longest contributions, using more evaluations than Young (Appendix C). The table below shows the instances of positive and negative judgements in the contributions of the two main participants.

Table 1. Traynor and Young, evaluation $(*=$ intensified, $\#=$ diminished $)$

\begin{tabular}{|l|c|c|c|c|}
\hline & \multicolumn{2}{|c|}{ Traynor } & \multicolumn{2}{c|}{ Young } \\
\hline \multicolumn{1}{|c|}{ Judgement } & & Percentage & \multicolumn{2}{c|}{ Percentage } \\
\hline +J: propriety & 0 & 0 & 1 & 11.1 \\
\hline -J: propriety & 1 & 3.2 & $5^{\#}$ & 55.5 \\
\hline +J: veracity & $1^{*}$ & 3.2 & 0 & 0 \\
\hline -J: veracity & 18 & 58.0 & 1 & 11.1 \\
\hline +J: capacity & 5 & 16.1 & 1 & 11.1 \\
\hline -J: capacity & 6 & 19.3 & 0 & 0 \\
\hline +J: tenacity & 0 & 0 & 1 & 11.1 \\
\hline Total & 31 & & 9 & \\
\hline
\end{tabular}

It is apparent from this table that the great majority of Traynor's evaluations are in the area of $-\mathrm{J}$ : veracity, for example:

he's admitted to lying so he he's compromised the integrity that we need from referees

The negative 'semantic prosodies' (Louw (1993: 157) associated with this pattern, through the frequent repetition of terms like dishonest, lie, lying, compro- 
mised the integrity, deceit, deceitful, credibility, create a superficial impression that a serious offence has been committed.

The positive capacity judgements, of which we have already seen an example, show Traynor's appreciation of McDonald in his professional role on the field. In the negative ones, there are direct references, at times, to the 'Celtic factor':

Dougie McDonald is afraid to give something against Celtic

Fear, of course, is an evaluation from the Affect system (Martin and White 2005: 35), rather than that of Judgement; it is coded as a Judgement because the speaker is evaluating McDonald as an effective/ineffective referee, which relates to his Capacity. Although Traynor is happy to concur with a general positive evaluation of McDonald's refereeing capacities, in the specific Celtic context his doubts emerge.

Young opposes to Traynor's occupation of the moral high ground a more sceptical view that attempts to deflate his interlocutor, for example by a humorous metaphor:

you don't hang a man for riding his bike with no lights on ( $\mathrm{t}-\mathrm{J}$ : propriety: diminished)

Whilst he admits that: 'you cannot defend lying' (-J veracity), he attempts to diminish the gravity of McDonald's offence by emphasising, as in this instance, the extreme severity of the punishment.

\subsection{Inferences}

We have seen that one participant in the debate is in favour of a severe punishment for the guilty referee, one for leniency. It may be that there is no need to invoke other mechanisms to account for this than the simple fact that the participants have different views on the matter. After all, as stated above, the extremes of evaluation displayed relate directly to the speakers' rhetorical goals. McDonald uses soft lexis to diminish the gravity of his behaviour. Traynor, who wishes the referee to be dismissed from his job, 'naturally' uses greater force (Martin and White 2005: 140) in his evaluations. Young does the opposite. But questions remain: why, for example, if Traynor holds McDonald in high esteem as a referee, does he insist on his complete removal from Scottish football? Presumably there would be other, less drastic alternatives such as a temporary ban which would both recognise the severity of the offence and yet allow Scottish football to benefit from McDonald's continuing services.

Chick Young's humorous parallel, and McDonald's term 'white lie' also deserve consideration. If it were possible, in the heated context of Scottish soccer, to find a disinterested observer, s/he might feel that McDonald's offence was not serious enough to merit instant dismissal. Covering up for a colleague, to save 
him from a poor mark, is not as grave a matter as, for example, taking money to influence the outcome of a game. An enquiry by the Scottish Referees' Association, the appropriate judicial body as well as, arguably, the only injured party, saw fit to punish this 'crime' with a mere verbal reprimand. The disparity between punishment and crime can, arguably, only be accounted for with reference to the sectarian backdrop to the episode, to what I have called 'the Celtic factor'.

In moving between text and context an analyst, who is ideally a 'disinterested observer', is guided, ultimately, by subjective intuition, a process nicely illustrated by Van Dijk (2000):

One of the elements of this context (NB: a mental model of the reader or the analyst!!!) may be our assumptions about the intentions of the speaker/ writer. In that case we say: by saying A, the speaker probably implies that $\mathrm{B}, \mathrm{C}$ and $\mathrm{D}$.

This means that in presenting, as I have done in this study, a vision of sectarianism in Scotland as a social 'fact', as a meaningful part of the mental models of participants in the discourse, I would seem to have imposed a part of my own 'mental model' on the data. Alternative accounts for these local discourse effects can readily be devised; the question is whether or not we find them more persuasive. Jim Traynor, for example, may simply have extremely high expectations of referees in the area of honesty. Indeed he says as much, allowing the inference that, in his opinion, this single lapse from perfect integrity is sufficient to justify McDonald's removal from his job:

the whole ethos of refereeing everything we cling to about referees is their honesty

It may be his idealisation of refereeing integrity, then, that underlies his objection to McDonald's behaviour. Likewise, in the phrase 'deceiving the Celtic manager', it is conceivable that this reference to Celtic does not relate to the sectarian context. Perhaps this particular Celtic manager is known to be extremely touchy about being lied to, a circumstance known to participants in the discussion, but not to the analyst.

Having admitted, then, that sectarianism may not be the only relevant social feature, I hope nevertheless to demonstrate that it could well be. It is, in fact, in the specific Old Firm context that the issue of integrity is most pressing for Traynor, and his references to Celtic are numerous:

- I don't see how Dougie McDonald can referee Celtic matches

- Dougie McDonald is afraid to give something against Celtic

- he cannot convince Celtic's fans the majority of them I would suggest now that all his decisions will be honest

- $\quad[$ He said] I deceived [...] the Celtic manager 
Moreover, his doubts in this context are echoed by the other guests, despite their expressed sympathy for McDonald:

KM: Craig Patterson as a former player put yourself in the position of the Celtic players as Jim's describing would they be happy with would they accept Dougie McDonald as as a referee for their next game?

Patterson: it'd be difficult now because it does it goes to credibility

Young: I do accept that if you were going into a Celtic game em that the media spotlight would be intense the pressure on him would be intense

Following a pragmatic course of reasoning, from the data towards its deictic referents (Verschueren 1999: 18), we arrive in brief steps at the door of sectarianism:

\begin{tabular}{|l|l|l|l|}
\hline \multicolumn{1}{|c|}{ Data } & \multicolumn{1}{|c|}{$\begin{array}{c}\text { Pragmatic } \\
\text { question }\end{array}$} & \multicolumn{1}{|c|}{ Possible solution } & $\begin{array}{l}\text { Relevant social } \\
\text { reality }\end{array}$ \\
\hline $\begin{array}{l}\text { I don't see how } \\
\text { Dougie McDon- } \\
\text { ald can referee } \\
\text { Celtic matches }\end{array}$ & Why not? & $\begin{array}{l}\text { Because Celtic are } \\
\text { a powerful actor in } \\
\text { Scottish soccer, and } \\
\text { are pressing to get } \\
\text { him out }\end{array}$ & $\begin{array}{l}\text { Celtic's ongoing } \\
\text { sense of repre- } \\
\text { senting a perse- } \\
\text { cuted cultural } \\
\text { minority }\end{array}$ \\
\hline
\end{tabular}

Or:

\begin{tabular}{|l|l|l|c|}
\hline \multicolumn{1}{|c|}{ Data } & $\begin{array}{l}\text { Pragmatic ques- } \\
\text { tion }\end{array}$ & \multicolumn{1}{c|}{ Possible solution } & $\begin{array}{c}\text { Relevant social } \\
\text { reality }\end{array}$ \\
\hline $\begin{array}{l}\text { I deceived the } \\
\text { Celtic manager }\end{array}$ & $\begin{array}{l}\text { What's special } \\
\text { about the Celtic } \\
\text { manager? }\end{array}$ & $\begin{array}{l}\text { Celtic have massive } \\
\text { support, their affairs } \\
\text { are closely followed } \\
\text { in the media, any lie } \\
\text { is fuel for conspiracy } \\
\text { theorists }\end{array}$ & ditto \\
\hline
\end{tabular}

Or:

\begin{tabular}{|l|l|l|c|}
\hline \multicolumn{1}{|c|}{ Data } & $\begin{array}{c}\text { Pragmatic ques- } \\
\text { tion }\end{array}$ & \multicolumn{1}{|c|}{ Possible solution } & $\begin{array}{c}\text { Relevant social } \\
\text { reality }\end{array}$ \\
\hline $\begin{array}{l}\text { he cannot con- } \\
\text { vince Celtic's } \\
\text { fans the majority } \\
\text { of them that all } \\
\text { his decisions will } \\
\text { be honest }\end{array}$ & Why not? & $\begin{array}{l}\text { Because he has told } \\
\text { a lie to the Celtic } \\
\text { manager, therefore } \\
\text { might have an anti- }\end{array}$ & ditto \\
Celtic bias & \\
\hline
\end{tabular}


The 'possible solution' column represents my attempt to 'mind-read' the speaker, along the lines of Van Dijk's hypothesis: 'by saying A, the speaker probably implies that B, C and D'. Though other possibilities can be devised, the sectarian factor does offer, at the very least, one plausible explanation.

\section{Conclusion}

My attention was initially drawn to the Tannadice incident by the patterns of speaker evaluation deployed, especially by Traynor, whose attitude to McDonald can only be termed 'paradoxical'. While recognising that McDonald is an excellent referee; indeed, conceding that his general conduct, through years of refereeing top-level matches, has marked him as 'an extremely honest referee', he nevertheless selects very strong negative evaluative patterns, characterising as 'deceit' what other participants are happy to call 'a white lie', 'not a major lie', and so on. Despite his high esteem for McDonald as a professional referee, he is pressing, strongly, for his removal because of one slip from the highest standards of integrity. As stated above, the SRA, the body responsible for moderating referees' behaviour, concluded that a verbal reprimand was an appropriate punishment for McDonald's naïve attempt to cover up for his partner. Yet Traynor's view won the day. Both Steven Craven, who resigned the day after 'whistlegate' broke in the press, and Dougie McDonald, who resigned after the referees' strike a short time later, were removed from refereeing Scottish soccer matches. This outcome was all the more surprising because several participants in the discussion lamented the low standards of refereeing in Scotland and complimented McDonald as a stand-out exception.

The neutral, a difficult animal to locate in the context of Scottish soccer, might feel that Young's call for leniency reflects the 'common sense' position. S/he would certainly feel that the following comment on the affair, from a Celtic fans' blog, represents an over-reaction:

Celtic must continue to pursue this issue until the very bitter end - the club and the fans will be vindicated on this one. For generations we have lamented the injustices heaped upon us, we now have an opportunity to effect lasting change within the bigots that run the game. ${ }^{8}$

Celtic F.C., as we have seen, were actively pushing the SFA for McDonald's removal. The lie that was told their manager, though clearly in no way damaging to Celtic F.C., seems to have become symbolic of a more fundamental lack of trust existing between the two bodies. The circumstance of the SRA punishing McDonald with a mere reprimand would no doubt have seemed, to Celtic, a 'slap in the face', as further evidence, probably, of an 'anti-Celtic' bias in high places.

It seems plausible to suggest that Traynor's extreme negative evaluation of McDonald's behaviour may derive from his awareness of 'the Celtic factor'. It 
may have stemmed from the fact that he recognises their likely response to the episode, and the impact it would probably have in the specific social context. Had the incident taken place at any other SPL game than one involving the Old Firm, it is possible that Traynor might have gone along with Young's more lenient line. Certainly the episode would have had no national resonance. It would have been dealt with internally by the SRA, and media interest would have been nil.

The study has, I hope, illustrated how evaluative language may serve as a revealing locus for highlighting the effects of contextual influences on discourse, and of the interplay between surrounding social factors and local discourse effects. Only by appreciating features of the social context, in this case, the sectarian background that has resulted in Celtic F.C. perceiving themselves as the victims of consistent institutional maltreatment, can we get a full picture of the factors that influence the evaluative standpoints of participants in discourse. It is also clear that how such evaluations are received by listeners will depend upon their own (sectarian or sporting) allegiances.

\section{Notes}

Soccer and Society: Routledge.

Football hooligans, ultras, tifo. Available online at: http://www.football-hooligans.org/ scotlands-secret-shame.html, accessed on 16 August 2011; see also: BBC online network at: http://news.bbc.co.uk/2/hi/special_report/1999/08/99/edinburgh_festival_99/415149.stm, accessed on 6 June 2011.

Panorama, Scotland's Secret Shame. Available online at: http://www.football-hooligans.org/ scotlands-secret-shame.html, accessed on 6 June 2011.

Pie and Bovril: The Staple Diet of Scottish Football. Available online at: http://www. pieandbovril.com/forum/index.php/topic/131774-the-scottish-media-against-celtic/, accessed on 10 August 2011.

5 Belfast Telegraph. Available online at: http:/www.belfasttelegraph.co.uk/sport/football/ scottish/ referees-are-biased-against-celtic-claims-gary-hooper-14995527.html\#, accessed on 16 August 2011. Hooper's remarks, though not specifically relevant to the sectarian issue, undoubtedly helped to fan the flames.

BBC Mobile. Sports Scotland. Available online at: http://news.bbc.co.uk/sport2/hi/scotland/ 9359793.stm, accessed on 16 August 2011.

Goal.com. Score to live. Available online at: http://www.goal.com/en/news/461/ scotland/2010/ 11/19/2221214/celtic-chairman-john-reid-referee-dougie-mcdonald-should, accessed on 10 August 2011.

The Lost Bhoys. Available online at: http://www.lostbhoys.com/2010/11/gary/just-anotherweek-for-glasgows-eastenders-\%E2\%80\%93-the-soap-opera-continues. Accessed on 16 August 2011.

I have chosen to view instances of Appreciation as tokens of + or - Judgement rather than present these instances in a separate table. In other words, in instances where the judgement is indirect ('the decision was incorrect') to jump directly to the implicit judgement on the author of the incorrect decision. 
Appendix A. Evaluation in Dougie McDonald interview, BBC Sportsound (1 November 2010)

\begin{tabular}{|c|c|c|c|}
\hline social esteem & AF & social sanction & AF \\
\hline there was a mistake & -J capacity & & \\
\hline $\begin{array}{l}\text { I've made a mess of } \\
\text { this }\end{array}$ & $-\mathrm{J}$ capacity & & \\
\hline \multirow{2}{*}{$\begin{array}{l}\text { [I've touched myself] } \\
\text { to indicate my mistake } \\
\text { it's an error }\end{array}$} & $-\mathrm{J}$ capacity & & [+J veracity] \\
\hline & & $\begin{array}{l}\begin{array}{l}\text { some premeditated idea between } \\
\text { either of us to concoct some sort of }\end{array} \\
\text { story }\end{array}$ & $\begin{array}{l}\text {-J veracity } \\
\text { (irrealis) }\end{array}$ \\
\hline \multirow{4}{*}{$\begin{array}{l}\text { a serious refereeing } \\
\text { error for giving the } \\
\text { original penalty }\end{array}$} & $\begin{array}{l}\text {-J capacity } \\
\text { (intens.) }\end{array}$ & & \\
\hline & & making up some sort of story & $\begin{array}{l}\text {-J veracity } \\
\text { (irrealis) }\end{array}$ \\
\hline & & I was happy to go along with it & $\begin{array}{l}\text {-J veracity } \\
\text { (dimin.) }\end{array}$ \\
\hline & & it was no big deal & $\begin{array}{l}\text {-J veracity } \\
\text { (dimin.) }\end{array}$ \\
\hline \multirow{4}{*}{$\begin{array}{l}\text { I'd immediately reali- } \\
\text { sedI was wrong }\end{array}$} & $+\mathrm{J}$ capacity & & \\
\hline & & you've lied & $-\mathrm{J}$ veracity \\
\hline & & $\begin{array}{l}\text { It was a white lie in the heat of the } \\
\text { moment }\end{array}$ & $\begin{array}{l}\text {-J veracity } \\
\text { (dimin.) }\end{array}$ \\
\hline & & it was not a premeditated act & $\begin{array}{l}\text {-J veracity } \\
\text { (intens. Irrealis) }\end{array}$ \\
\hline \multirow[t]{6}{*}{ it was a mistake } & -J capacity & & \\
\hline & & $\begin{array}{l}\text { there's not a person on this earth who } \\
\text { hasn't told a lie for what they think } \\
\text { are the right reasons }\end{array}$ & $\begin{array}{l}\text {-J veracity } \\
\text { (dimin.) }\end{array}$ \\
\hline & & $\begin{array}{l}\text { telling the observer the incorrect } \\
\text { situation }\end{array}$ & $\begin{array}{l}\text { J veracity } \\
\text { (dimin.) }\end{array}$ \\
\hline & & the truth would have to be told & $\begin{array}{l}+\mathrm{J} \text { veracity } \\
\text { (irrealis) }\end{array}$ \\
\hline & & I'd told Hugh the truth & $+\mathrm{J}$ veracity \\
\hline & & $\begin{array}{l}\text { it was important that the truth was } \\
\text { told to the media }\end{array}$ & $+\mathrm{J}$ veracity \\
\hline \multirow[t]{3}{*}{ I've made an error } & -J capacity & & \\
\hline & & I've held my hands up to that error & $+\mathrm{J}$ veracity \\
\hline & & $\begin{array}{l}\text { I content myself with knowing that } \\
\text { I corrected it as soon as I possibly } \\
\text { could }\end{array}$ & $+\mathrm{J}$ veracity \\
\hline \multirow[t]{2}{*}{$\begin{array}{l}\text { my ability as a referee } \\
\text { is unaffected }\end{array}$} & $+\mathrm{J}$ capacity & & \\
\hline & & referees can't be trusted & $-\mathrm{J}$ veracity \\
\hline
\end{tabular}




\begin{tabular}{|c|c|c|c|}
\hline social esteem & $\mathbf{A F}$ & social sanction & $\mathbf{A F}$ \\
\hline & & $\begin{array}{l}\text { it would have been the easiest thing } \\
\text { in the world to leave the mistake } \\
\text { and award the penalty kick the more } \\
\text { difficult thing the more courageous } \\
\text { thing the more honest thing was to } \\
\text { overturn and make sure that a right } \\
\text { decision was arrived at }\end{array}$ & $\begin{array}{l}+\mathrm{J} \text { propriety/ } \\
\text { tenacity intens. }\end{array}$ \\
\hline & & $\begin{array}{l}\text { the untruth was told to an observer } \\
\text { and that's all that's happened here an } \\
\text { untruth about the incident }\end{array}$ & $-\mathrm{J}$ propriety \\
\hline & & $\begin{array}{l}\text { refereeing integrity a hundred per- } \\
\text { center and will remain that way }\end{array}$ & $+\mathrm{J}$ propriety \\
\hline \multirow[t]{4}{*}{ I made an error } & -J capacity & & \\
\hline & & I corrected that error & $+\mathrm{J}$ propriety \\
\hline & & $\begin{array}{l}\text { my part in the two of us having this } \\
\text { story for the observer and ultimately } \\
\text { for Neil Lennon }\end{array}$ & $-\mathrm{J}$ veracity \\
\hline & & $\begin{array}{l}\text { I corrected that the moment I had an } \\
\text { opportunity to do so }\end{array}$ & $+\mathrm{J}$ propriety \\
\hline $\begin{array}{l}\text { nothing to do with me } \\
\text { making any errors }\end{array}$ & $-\mathrm{J}$ capacity & & \\
\hline
\end{tabular}

Appendix B. Evaluation, Jim Traynor, BBC Sportsound (1 November 2010)

\begin{tabular}{|c|c|c|c|}
\hline social esteem & AF & social sanction & AF \\
\hline \multirow[t]{2}{*}{$\begin{array}{l}\text { I don't see how Dougie } \\
\text { McDonald can referee } \\
\text { Celtic matches }\end{array}$} & t-J capacity & & \\
\hline & & $\begin{array}{l}\text { Dougie McDonald was dishonest he } \\
\text { calls it a white lie but it is a lie he } \\
\text { was dishonest }\end{array}$ & $\begin{array}{l}-\mathrm{J} \text { veracity (in- } \\
\text { tens.) }\end{array}$ \\
\hline \multirow{2}{*}{$\begin{array}{l}\text { he made a wrong call } \\
\text { changed it }\end{array}$} & $+\mathrm{J}$ capacity & & \\
\hline & & $\begin{array}{l}\text { why he had to come up with this ly- } \\
\text { ing for the supervisor }\end{array}$ & $-\mathrm{J}$ veracity \\
\hline $\begin{array}{l}\text { he made the wrong } \\
\text { decision }\end{array}$ & t-J: capacity ${ }^{9}$ & & \\
\hline \multirow{3}{*}{\begin{tabular}{|l|} 
what happened on the \\
pitch which ultimately \\
was correct
\end{tabular}} & $\mathrm{t}+\mathrm{J}$ capacity & & \\
\hline & & $\begin{array}{l}\text { Dougie McDonald is seen to be dis- } \\
\text { honest }\end{array}$ & $-\mathrm{J}$ veracity \\
\hline & & $\begin{array}{l}\text { the one thing we need from our refer- } \\
\text { ees is honesty }\end{array}$ & $t-J$ veracity \\
\hline
\end{tabular}




\begin{tabular}{|c|c|c|c|}
\hline social esteem & AF & social sanction & AF \\
\hline \multirow[t]{2}{*}{$\begin{array}{l}\text { his mistakes on the } \\
\text { pitch were honest }\end{array}$} & $\mathrm{t}+\mathrm{J}$ capacity & & \\
\hline & & he has admitted to lying & $-\mathrm{J}$ veracity \\
\hline $\begin{array}{l}\text { Dougie McDonald is } \\
\text { afraid to give some- } \\
\text { thing against Celtic }\end{array}$ & $\begin{array}{l}\mathrm{t}-\mathrm{J} \text { capacity } \\
\text { (irrealis) }\end{array}$ & & \\
\hline $\begin{array}{l}\text { just a a few seconds' } \\
\text { stupidity }\end{array}$ & -J capacity & & \\
\hline he later rectified & $+\mathrm{J}$ capacity & & \\
\hline $\begin{array}{l}\text { leaves him in an un- } \\
\text { tenable position }\end{array}$ & t-J capacity & & \\
\hline \multirow[t]{5}{*}{$\begin{array}{l}\text { I don't see how he can } \\
\text { continue to referee } \\
\text { Celtic matches }\end{array}$} & t-J capacity & & \\
\hline & & $\begin{array}{l}\text { he's been a bad boy according to } \\
\text { Chick well that's fine }\end{array}$ & $-\mathrm{J}$ propriety \\
\hline & & $\begin{array}{l}\text { he cannot convince Celtic's fans the } \\
\text { majority of them I would suggest } \\
\text { now that all his decisions will be } \\
\text { honest }\end{array}$ & $-\mathrm{J}$ veracity \\
\hline & & $\begin{array}{l}\text { I believe that Dougie McDonald is } \\
\text { an extremely honest referee as it } \\
\text { happens }\end{array}$ & $\begin{array}{l}+\mathrm{J} \text { veracity (in- } \\
\text { tens.) }\end{array}$ \\
\hline & & $\begin{array}{l}\text { but the fact is he's admitted to lying } \\
\text { so he he's compromised the integrity } \\
\text { that we need from referees }\end{array}$ & $-\mathrm{J}$ veracity \\
\hline \multirow[t]{10}{*}{$\begin{array}{l}\text { a top-class one of the } \\
\text { best referees in the } \\
\text { country }\end{array}$} & $\begin{array}{l}\mathrm{J} \text { capacity } \\
\text { (intens.) }\end{array}$ & admitting to dishonesty to deceit? & $-\mathrm{J}$ veracity \\
\hline & & $\begin{array}{l}\text { but the whole ethos of refereeing } \\
\text { everything we cling to about referees } \\
\text { is their honesty }\end{array}$ & $t-J$ veracity \\
\hline & & $\begin{array}{l}\text { I have been dishonest I have been } \\
\text { deceitful }\end{array}$ & $-\mathrm{J}$ veracity \\
\hline & & the issue is the lying & $-\mathrm{J}$ veracity \\
\hline & & the issue is the lying & -J veracity \\
\hline & & the issue is the lying & $-\mathrm{J}$ veracity \\
\hline & & $\begin{array}{l}\text { not a major lie ok now it's a small } \\
\text { lie it's a lie he's been dishonest he's } \\
\text { been deceitful by his own admission } \\
\text { he's been dishonest }\end{array}$ & $\begin{array}{l}-\mathrm{J} \text { veracity (in- } \\
\text { tens.) }\end{array}$ \\
\hline & & $\begin{array}{l}\text { the one thing we need is the integrity } \\
\text { of referees }\end{array}$ & $t-J$ veracity \\
\hline & & $\begin{array}{l}\text { there's a problem when a top-class } \\
\text { referee admits to deceit }\end{array}$ & $-\mathrm{J}$ veracity \\
\hline & & $\begin{array}{l}\text { I was dishonest I deceived the super- } \\
\text { visor I deceived the Celtic manager }\end{array}$ & $-\mathrm{J}$ veracity \\
\hline
\end{tabular}




\begin{tabular}{|l|l|l|l|}
\hline social esteem & AF & social sanction & AF \\
\hline & $\begin{array}{l}\text { the problem is for Dougie McDonald } \\
\text { credibility }\end{array}$ & - J veracity \\
\hline & $\begin{array}{l}\text { the integrity of him as a referee } \\
\text { comes because he has admitted to } \\
\text { deceit }\end{array}$ & - J veracity \\
\hline & he has admitted to being dishonest & - J veracity \\
\hline & $\begin{array}{l}\text { the referee's integrity and one of } \\
\text { them saying I've been dishonest } \\
\text { that's all }\end{array}$ & - J veracity \\
\hline
\end{tabular}

Appendix C. Evaluation, Chick Young, BBC Sportsound (1 November 2010)

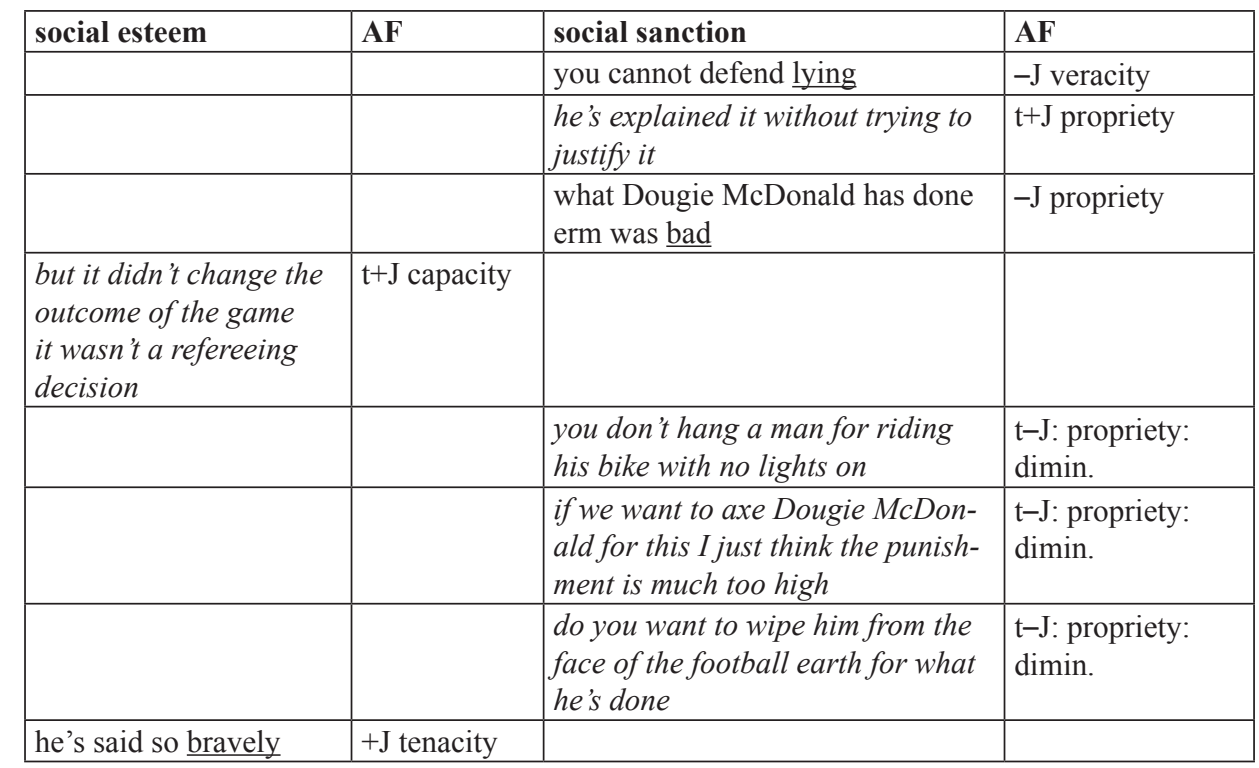

\section{References}

Baines, Roger (2011) “The journalist, the translator, the player and his agent: games of (mis)representation and (mis)translation in British media reports about non-anglophone football players". In: Wilson, Rita and Brigid Maher (eds.) Words, Images and Performances in Translation. London and New York: Continuum, 100-118.

Baines, Roger (2013) "Translation, globalization and the elite migrant athlete". The Translator 19 (2), 207-228. St. Jerome: https://www.stjerome.co.uk/tsa/issue/2692/

Benwell, Bethan and Elizabeth Stokoe (2006) Discourse and Identity. Edinburgh: Edinburgh University Press.

Bishop, Hywel and Adam Jaworski (2003) “'We beat 'em': nationalism and the hegemony of homogeneity in the British press reportage of Germany versus England during Euro 2000". Discourse and Society 14 (3), 243-271. 
Bloor, Thomas and Meriel Bloor (2003) The Functional Analysis of English, a Hallidayan Approach. London: Arnold.

Brazil, David (1992) The Communicative Value of Intonation in English. Cambridge: Cambridge University Press.

Campbell, Tom (2004) Celtic's Paranoia... All in the Mind? Ayr: Fort Publishing Ltd.

Chilton, Paul (1996) Security Metaphors: Cold War Discourse from Containment to Common House. Bern and New York: Peter Lang.

Chouliaraki, Lilie and Norman Fairclough (1999) Discourse in Late Modernity: Rethinking Critical Discourse Analysis. Edinburgh: Edinburgh University Press.

Chovanec, Jan (2008) "Focus on form: foregrounding devices in football reporting". Discourse and Communication 2 (3), 219-242.

De Cillia, Rudolph, Martin Reisigl and Ruth Wodak (1999) "The discursive construction of national identities". Discourse and Society 10 (2), 149-173.

Devine, T.M. (2008) "The end of disadvantage? The descendants of Irish-Catholic immigrants in modern Scotland since 1945”. In Mitchell, Martin J. (ed.) The Irish in Scotland. Edinburgh: John Donald.

Findlay, Bill (2008) "It's a Dutch invention, but we started it in Scotland: The strange case of Scottish football". Etudes Ecossaises 261-273. http://etudesecossaises.revues.org/index100.html. Accessed on 6 June 2011.

Fowler, Roger (1991) Language in the News: Discourse and Ideology in the Press. London and New York: Routledge.

Fairclough, Norman (1992) Discourse and Social Change. Cambridge: Polity Press.

Fairclough, Norman (1995) Critical Discourse Analysis: the Critical Study of Language. NewYork: Longman.

Featherstone, Simon (2009) Englishness: Twentieth-century Popular Culture and the Forming of English Identity. Edinburgh: Edinburgh University Press.

Halliday, M.A.K. and Christian Matthiessen (2004) An Introduction to Functional Grammar. London: Hodder Arnold.

Hopcraft, Arthur (1968) The Football Man: People and Passions in Soccer. London: Collins.

Hunston, Susan and Geoff Thompson (1999) "Evaluation: an introduction". In: Hunston, Susan and Geoff Thompson (eds.) Evaluation in Text. Authorial Stance and the Construction of Discourse. Oxford: Oxford University Press, 1-27.

Hutchby, Ian and Robin Wooffitt (1998) Conversation Analysis: Principles, Practices and Applications. Cambridge: Polity.

Hyatt, David (2005) "Time for a change: a critical discoursal analysis of synchronic context with diachronic relevance". Discourse and Society 16 (4), 515-534.

Jansen, Sue Curry and Szabó, Don (1994) "The sport/war metaphor: hegemonic masculinity, the Persian Gulf War, and the new world order". Sociology of Sport Journal 11, 1-17.

Kaufmann, Eric (2008) “The Orange Order in Scotland since 1860: a social analysis". In: Mitchell, Martin J. (ed.) The Irish in Scotland. Edinburgh: John Donald.

Lavric, Eva, Gerhard Pisek, Andrew Skinner and Wolfgang Stadler (eds.) (2008) The Linguistics of Football. Tübingen: Gunter Narr.

Lazar, Michelle M. (2007) Feminist Critical Discourse Analysis: Gender, Power and Ideology in Discourse. Basingstoke and New York: Palgrave Macmillan.

Louw, Bill (1993) "Insincerity in the text or irony in the writer? The diagnostic potential of semantic prosodies." In: Baker, Mona, Gill Francis and Elena Tognini-Bonelli (eds.) Text and Technology. Amsterdam: John Benjamins, 157-176.

Malinowski, Bronislaw (1923) "The problem of meaning in primitive languages". Supplement to Ogden, Charles Kay and Ivor Armstrong Richards The Meaning of Meaning: A Study of the Influence of Language upon Thought and the Science of Symbolism. New York: Harcourt Brace Jovanovich. 
Martin, James R. (1999) "Beyond exchange: appraisal systems in English". In: Hunston, Susan and Geoff Thompson (eds.) Evaluation in Text. Authorial Stance and the Construction of Discourse. Oxford: Oxford University Press, 142-175.

Martin, James R. and Peter R.R. White (2005) The Language of Evaluation: Appraisal in English. Basingstoke and New York: Palgrave Macmillan.

Meyerhoff, Miriam (2006) Introducing Sociolinguistics. London and New York: Routledge.

Russell, David (1997) Football and the English: A Social History of Association Football in England, 1863-1995. Preston: Carnegie Publishing.

Szabó, Róbert Győri (2012 ) "Identity and soccer in Corsica”. Soccer and Society 13 (1), 36-55.

Taylor, Rogan and Andrew Ward (1995) Kicking and Screaming: An Oral History of Football in England. London: Robson Books.

Van Dijk, Teun A. (1991) Racism and the Press. London and New York: Routledge.

Van Dijk, Teun A. (2000) “Cognitive discourse analysis: an introduction”. At: http://www.discourses.org/UnpublishedArticles/cogn-dis-anal.htm, accessed on 16 August 2011.

Van Dijk, Teun A. (2001) "Critical discourse analysis”. In: Tannen, Deborah, Deborah Schiffrin and Heidi Hamilton (eds.) Handbook of Discourse Analysis. Oxford: Blackwell.

Verschueren, Jeff (1999) Understanding Pragmatics. London: Arnold and New York: OUP.

Weiss, Gilbert and Ruth Wodak (2003) "Introduction: Theory, interdisciplinarity and critical discourse analysis". In: Weiss, Gilbert and Ruth Wodak (eds.) Critical Discourse Analysis: Theory and Interdisciplinarity. Basingstoke and New York: Palgrave Macmillan.

Wodak, Ruth and Rudolf De Cillia (2007) "Commemorating the past: the discursive construction of official narratives about the 'Rebirth of the Second Austrian Republic'." Discourse and Communication 1 (3), 315-341.

Wolfram, Walt (1991) Dialects and American English. Englewood Cliffs NJ: Prentice Hall.

Douglas Ponton is a researcher in English Language at the Department of Political and Social Sciences, University of Catania, Sicily. He studied English Literature at Cambridge University, and has a $\mathrm{PhD}$ in English and American studies from the University of Catania. He has lived in Italy for twenty years. His research interests include interactive socio-linguistics, conversation analysis, corpus linguistics and political discourse analysis. He has published work on the discourse of contemporary politicians such as Churchill, Thatcher and Blair. As well as sport, current research fields include contemporary music and the discourse of religious groups.

Address: Douglas Ponton, Facoltà di Scienze Politiche, università degli Studi di Catania, Via Vittorio Emanuele II 49, Catania 95131, Italy. [email: dmponton@gmail.com] 
